\title{
Interlinking the Shariah Compliant Stocks in India: An Analysis Using Granger Causality
}

Taran Matharu*

\begin{abstract}
With the growth of the Shariah-compliant stocks in India, the opportunities are also increasing. The investors need to know how they can predict the future of the stocks by studying a smaller number of stocks. This paper deals with the link between different Shariah-compliant stocks available in India. A research was done on S\&P BSE 500 Shariah, Nifty Shariah 25, Nifty 50 Shariah and NIFTY 500 Shariah. The study revealed the interdependence of the shares. It helped locate the function as well as the driver of the stock.
\end{abstract}

Keywords: Shariah Compliant Stocks, S\&P BSE 500 Shariah, NIFTY Shariah 25, Nifty 50 Shariah, NIFTY 500 Shariah

\section{Introduction}

India is the seventh-largest economy with the growth rate of $6 \%-7 \%$ annually. According to the Centre for Economics and Business Research (CEBR), India would become the fifth largest economy by 2020. There are around 7000 listed companies in BSE and around 1700 listed companies in NSE. Out of this, approximately 1077 companies qualified as Shariah-compliant with their own assets valued at INR 21.1 trillion and approximately 449 companies qualified as Shariah-compliant with their own assets valued at 20.4 trillion.

*Western Michigan University, Kalamazoo, USA;

taran.matharu@wmich.edu 
Shariah-compliant stocks are bound with the 'Shariah law' or 'Islamic law' which is the religious law. Therefore, they follow the principles of the Islamic religion (Sharia, 2019). The word 'Shariah' means the unchangeable divine law of God as interpreted by human scholars (Sharia, 2019). Shariah complaints are known to be socially responsible investments all over the world. Shariahcompliant stocks were introduced in the market in the late 1960s. Shariah principles are quite strict with certain things like tobacco, pornography, alcohol, pork products, gambling and military equipment. The Shariah-compliant stocks do not allow investing in the above-mentioned things. Further, Muslims are not allowed to either invest in short selling or leverage in usable stocks.

Shariah-compliant stocks have a wide scope in India with many Indian investors (Muslim investors as well as non-Muslim investors) coming up to invest in the Shariah-compliant stocks. However, investors find it difficult to predict the fate of the stock market. This research is done on the four main Shariah-compliant stocks of India- S\&P BSE 500 Shariah, Nifty Shariah 25 Nifty 50 Shariah and NIFTY 500 Shariah. Through the use of Granger Causality, it becomes easy to predict the driver of the stock market. It helps predict which stock market index offers direction to the other stock market index. Further, this helps investors to study only selective stocks. It allows them to keep a check on two or three driver stocks and consequently make a decision on other Shariah stocks according to the estimation.

\section{Research Objectives}

- To know about the working and functionality of Shariahcompliant stocks

- To understand the link between the stocks

\section{Literature Review}

Since investors are really interested in the Shariah stock, many Indian researchers have made an effort to write research papers on the Islamic stock exchange. Ghosh and Srinivasan (2013) in their study tried explaining the Shariah investment and its future growth in India. They investigated the risk and returns in Shariah 
investment. The paper proved that Nifty Shariah is not performing as well as the BSE Tasis Shariah Index.

Natarajan and Dharani (2012) tried to find answers to some of the questions related to Islamic investments. In their paper, they not only mention the risk and returns of the Shariah shares and Islamic investments but also about the thoughts of ethical investors in Shariah investment in India. From their research, they concluded that the Shariah investments have equal risk and give the same result as other equity investments. Besides, the researcher also suggested that the ethical investor prefers Shariah investments as they were considered to be the best in the market.

Ghosh \& Srinivasan (2013) carried out an investigation to understand the investment pattern in India. He attempted to find out if it was rational (positive as it would help in the growth of the economy) or driven by sentiments (negative it would conclude the weak economy's efficiency). Through his research, he came to the conclusion that the Indian market is rational thereby highlighting the rapid growth of the Indian economy.

Karim, Linn and Karim (2017) discussed in their paper that Islamic stock markets get positively affected by GDP growth and inflation of the country. The study was done on 10 countries which covered international investors and policymakers. They proved that the high depression in GPD and inflation rate would lead to more integration in the Islamic stock markets which will help Islamic stock markets to protect the countries' inflation rate.

Mansoori (2011) carried out a study to investigate the Shariah legitimacy under Islamic Banking. It talks about the classical Islamic application and the laws followed under modern Islamic finance. The researcher proved that the Islamic bank does not believe in earning money by taking a huge interest. They deal in assets rather than money. It negated Shariah-compliant banking and emphasised on complete Shariah-based banking.

Mohammad (2016) analysed the relationship between the Islamic stock markets and macroeconomic variables of India. He informed that anyone following Islamic stock markets can predict the future of the macroeconomic variables (like CPI, INT, MON and ER). The 
analysis revealed that Islamic stock has a great future in the market with the world economy as they work with ethics and social justice.

Singh and Sheng (2013) in their paper discusses the issues that crop up in establishing and operating Islamic stock markets worldwide. Lessons mentioned are useful for architects and investors of Islamic stock markets. For example, investors should invest in long-term stocks, architects should know the complex literature of share price and the mechanisms of the two kinds of agents who participate in stock markets and so on. Islamic stock markets are attracted by the equitable and stability of the stocks in the market.

In their study, Irfan and Tanwar (2017) work on the relationship between Shariah indices and non-Shariah indices of India from both the investor and the industrialist's point of view. The results of the research show that Shariah indices and non-Shariah indices are co-integrated in nature, have long-run equilibrium and are either directional or bi-directional.

Tyagi and Rizwan (2012), in their study, deal with the analysis of Islamic finances all over the world in Shariah indices or Shariah businesses. The study concludes by advising the investor to invest in companies which have Shariah stocks with the purpose of having similar profit or losses or the same as other non-Shariah stocks from Sensex.

The study conducted by Dharani and Natarajan (2011) aimed to understand the performance of the Nifty index and Nifty Shariah index (risk and return) in the market for 4 years. The results proved that both the indices were not performing in risk-adjusted return and both indices were less volatile. The research concluded that both Nifty index and Nifty Shariah index performed similarly in India.

Dharani, Vijayakumar, \& Natarajan (2015), attempted to study the pattern of Indian Shariah-compliant stocks with the help of Augmented Dickey-Fuller Test and Q statistics. The researchers observed that the Shariah-compliant stock's returns are stationary at every level. The researchers observed that the Shariah-compliant stock's returns are stationary at every level and they concluded that Shariah-compliant stocks in India are volatility clustered. 
Nisar (2008) studied the chances that Indian stock market offers the Shariah-compliant stocks as compared to the Islamic country's stock performances. He used Dow Jones, FTSE and other stocks over the world for the study. The researcher also suggested the institutions, domestic investor, various sector's investor like IT, pharmaceuticals, automobile and core sectors (like energy, steel, cement, mining, and so on) to select Indian stock market like shariah-compliant stocks for investment as its returns were better as compared to others.

Back in 2002, Nisar studied Islamic banking and finances to know its current status in the Indian stock market and explained their origin in India. The most trusted investment in India is 'Barkat investment group' as a result of which the comparatively new ones in the market like Islamic banking and finances fail to win over the trust of the investors. The study revealed that this was the main cause of worry for Islamic bankers and economists.

Khatakhatay and Nisar (2007) in their paper on Shariah compliance norms highlighted that the companies preferred Islamic investments like equity to get ownership and after research, they recommended the investor to invest in complaint companies rather than investing in industries like shipping, hotels, and many others. However, the paper's objective was inaccurate since the market prices of the shares are not dependent on the corresponding value that is given by the company's cash hoard, by the receivables or by payables.

From all the above, the gap that can be easily rectified is that none of these researches has discussed the inter-dependence of Islamic stock exchange, where the investors can identify the driver index and driven index so that the investor can make the prediction of the future movements of the driven index by following the driver index.

\section{Research Methodology}

The paper makes an attempt to know which stock market index is leading the market and which stock market index directs the other stock market index. The 'Granger Causality' has been used to find this out. 


\subsection{What is Granger Causality?}

In the 1960s, Granger Causality was developed by Professor Clive Granger. Granger Causality is a statistical concept purely based on predictions. It helps to know who the driver is and who is getting driven. For example, who the engine is (contains information) and who the coach is (go according to the information-assuming) in the market. Here, $X_{1}$ has the information and assuming that $X_{2}$ is following the information. Studying $X_{1}$ can help understand easily where $X_{2}$ would be going. The two variables are $X_{1}$ and $X_{2}$ and the bivariate linear autoregressive model is

$$
\begin{aligned}
& X_{1}(t)=\sum j=1 p A_{11}, j X_{1}(t-j)+\sum j=1 p A_{12}, j X_{2}(t-j)+E_{1}(t) \\
& X_{2}(t)=\sum j=1 p A_{21}, j X_{1}(t-j)+\sum j=1 p A_{22}, j X_{2}(t-j)+E_{2}(t)
\end{aligned}
$$

Important assumptions are that it is acceptable by the linear model and it is covariance stationary.

\subsection{Results}

For the study we have taken four stock market indices - S\&P BSE 500 Shariah, Nifty Shariah 25 Nifty 50 Shariah and NIFTY 500 Shariah. Due to a macro-economic study, the cut off is kept at $80 \%$.

\begin{tabular}{|c|c|c|c|c|c|c|}
\hline \multicolumn{5}{|c|}{ Granger Causality Test: $Y=f(X)$} & \multirow[b]{2}{*}{ Occurrence } & \multirow[b]{2}{*}{$\begin{array}{l}\text { Accept/ } \\
\text { Reject }\end{array}$} \\
\hline Model & Res.DF & Diff. DF & $\mathrm{F}$ & p-value & & \\
\hline $\begin{array}{l}\text { Complete } \\
\text { model }\end{array}$ & 812 & & & & 0.337682168 & Reject \\
\hline $\begin{array}{l}\text { Reduced } \\
\text { model }\end{array}$ & 813 & -1 & 0.19086015 & 0.66231783 & & \\
\hline \multicolumn{5}{|c|}{ Granger Causality Test: $X=f(Y)$} & & \\
\hline Model & Res.DF & Diff. DF & $\mathrm{F}$ & p-value & Occurrence & $\begin{array}{l}\text { Accept/ } \\
\text { Reject }\end{array}$ \\
\hline $\begin{array}{l}\text { Complete } \\
\text { model }\end{array}$ & 812 & & & & 0.693260622 & Reject \\
\hline $\begin{array}{l}\text { Reduced } \\
\text { model }\end{array}$ & 813 & -1 & 1.04597984 & 0.30673938 & & \\
\hline
\end{tabular}

Table 1: Granger Causality for S\&P BSE 500 Shariah and Nifty Shariah 25 
Table 2: Granger Causality for S\&P BSE 500 Shariah and Nifty50 Shariah

\begin{tabular}{|c|c|c|c|c|c|c|}
\hline \multicolumn{4}{|c|}{ Granger Causality Test: $Y=f(X)$} & \multirow[b]{2}{*}{ p-value } & \multirow[b]{2}{*}{ Occurrence } & \multirow[b]{2}{*}{$\begin{array}{l}\text { Accept/ } \\
\text { Reject }\end{array}$} \\
\hline Model & $\begin{array}{l}\text { Res. } \\
\text { DF }\end{array}$ & $\begin{array}{l}\text { Diff. } \\
\text { DF }\end{array}$ & $\mathrm{F}$ & & & \\
\hline $\begin{array}{l}\text { Complete } \\
\text { model }\end{array}$ & 812 & & & & 0.705090445 & Reject \\
\hline $\begin{array}{l}\text { Reduced } \\
\text { model }\end{array}$ & 813 & -1 & 1.09849013 & 0.29490955 & & \\
\hline \multicolumn{7}{|c|}{ Granger Causality Test: $\mathrm{X}=\mathrm{f}(\mathrm{Y})$} \\
\hline Model & Res.DF & $\begin{array}{l}\text { Diff. } \\
\text { DF }\end{array}$ & $\mathrm{F}$ & $\mathrm{p}$-value & Occurrence & $\begin{array}{l}\text { Accept/ } \\
\text { Reject }\end{array}$ \\
\hline $\begin{array}{l}\text { Complete } \\
\text { model }\end{array}$ & 812 & & & & 0.899955519 & Accept \\
\hline $\begin{array}{l}\text { Reduced } \\
\text { model }\end{array}$ & 813 & -1 & 2.71101539 & 0.10004448 & & \\
\hline
\end{tabular}

S\&P BSE 500 Shariah is a function of NIFTY 50 Shariah

Table 3: Granger Causality for S\&P BSE 500 Shariah and Nifty500 Shariah

\begin{tabular}{|c|c|c|c|c|c|c|}
\hline \multicolumn{5}{|c|}{ Granger Causality Test: $Y=f(X)$} & & \\
\hline Model & $\begin{array}{l}\text { Res. } \\
\text { DF }\end{array}$ & $\begin{array}{l}\text { Diff. } \\
\text { DF }\end{array}$ & $\mathrm{F}$ & p-value & Occurrence & $\begin{array}{l}\text { Accept/ } \\
\text { Reject }\end{array}$ \\
\hline $\begin{array}{l}\text { Complete } \\
\text { model }\end{array}$ & 812 & & & & 0.744595218 & Reject \\
\hline $\begin{array}{l}\text { Reduced } \\
\text { model }\end{array}$ & 813 & -1 & 1.29532414 & 0.25540478 & & \\
\hline \multicolumn{5}{|c|}{ Granger Causality Test: $X=f(Y)$} & & \\
\hline Model & $\begin{array}{l}\text { Res. } \\
\text { DF }\end{array}$ & $\begin{array}{c}\text { Diff. } \\
\text { DF }\end{array}$ & $\mathrm{F}$ & $\mathrm{p}$-value & Occurrence & $\begin{array}{l}\text { Accept/ } \\
\text { Reject }\end{array}$ \\
\hline $\begin{array}{l}\text { Complete } \\
\text { model }\end{array}$ & 812 & & & & 0.869712032 & Accept \\
\hline $\begin{array}{l}\text { Reduced } \\
\text { model }\end{array}$ & 813 & -1 & 2.29371317 & 0.13028797 & & \\
\hline
\end{tabular}

S\&P BSE 500 Shariah is a function of NIFTY 500 Shariah 
Table 4: Granger Causality for Nifty Shariah 25 and Nifty50 Shariah

\begin{tabular}{|c|c|c|c|c|c|c|}
\hline \multicolumn{5}{|c|}{ Granger Causality Test: $Y=f(X)$} & & \\
\hline Model & Res.DF & Diff. DF & $\mathrm{F}$ & p-value & Occurrence & $\begin{array}{c}\text { Accept/ } \\
\text { Reject }\end{array}$ \\
\hline $\begin{array}{l}\text { Complete } \\
\text { model }\end{array}$ & 812 & & & & 0.708271182 & Reject \\
\hline $\begin{array}{l}\text { Reduced } \\
\text { model }\end{array}$ & 813 & -1 & 1.11307258 & 0.29172882 & & \\
\hline \multicolumn{5}{|c|}{ Granger Causality Test: $X=f(Y)$} & & \\
\hline Model & Res.DF & Diff. DF & $\mathrm{F}$ & p-value & Occurrence & $\begin{array}{c}\text { Accept/ } \\
\text { Reject }\end{array}$ \\
\hline $\begin{array}{l}\text { Complete } \\
\text { model }\end{array}$ & 812 & & & & 0.84649582 & Accept \\
\hline $\begin{array}{l}\text { Reduced } \\
\text { model }\end{array}$ & 813 & -1 & 2.04089389 & 0.15350418 & & \\
\hline
\end{tabular}

Nifty Shariah 25 is a function of NIFTY 50 Shariah

Table 5: Granger Causality for Nifty Shariah 25 and Nifty 500 Shariah

\begin{tabular}{|c|c|c|c|c|c|c|}
\hline \multicolumn{7}{|c|}{ Granger Causality Test: $\mathrm{Y}=\mathrm{f}(\mathrm{X})$} \\
\hline Model & Res.DF & $\begin{array}{l}\text { Diff. } \\
\text { DF }\end{array}$ & $\mathrm{F}$ & $\mathrm{p}$-value & Occurrence & $\begin{array}{l}\text { Accept/ } \\
\text { Reject }\end{array}$ \\
\hline $\begin{array}{l}\text { Complete } \\
\text { model }\end{array}$ & 812 & & & & 0.791604963 & Reject \\
\hline $\begin{array}{l}\text { Reduced } \\
\text { model }\end{array}$ & 813 & -1 & 1.58506083 & 0.20839504 & & \\
\hline \multicolumn{7}{|c|}{ Granger Causality Test: $X=f(Y)$} \\
\hline Model & Res.DF & $\begin{array}{l}\text { Diff. } \\
\text { DF }\end{array}$ & F & $\mathrm{p}$-value & Occurrence & $\begin{array}{l}\text { Accept/ } \\
\text { Reject }\end{array}$ \\
\hline $\begin{array}{l}\text { Complete } \\
\text { model }\end{array}$ & 812 & & & & 0.877451773 & Accept \\
\hline $\begin{array}{l}\text { Reduced } \\
\text { model }\end{array}$ & 813 & -1 & 2.38942438 & 0.12254823 & & \\
\hline
\end{tabular}

Nifty Shariah 25 is a function of NIFTY 500 Shariah 
Table 6: Granger Causality for Nifty 50 Shariah and Nifty 500 Shariah

\begin{tabular}{|c|c|c|c|c|c|c|}
\hline \multicolumn{5}{|c|}{ Granger Causality Test: $\mathrm{Y}=\mathrm{f}(\mathrm{X})$} & \multirow[b]{2}{*}{ Occurrence } & \multirow[b]{2}{*}{$\begin{array}{l}\text { Accept/ } \\
\text { Reject }\end{array}$} \\
\hline Model & Res.DF & $\begin{array}{l}\text { Diff. } \\
\text { DF }\end{array}$ & $\mathrm{F}$ & p-value & & \\
\hline $\begin{array}{l}\text { Complete } \\
\text { model }\end{array}$ & 812 & & & & 0.171705198 & Reject \\
\hline $\begin{array}{l}\text { Reduced } \\
\text { model }\end{array}$ & 813 & -1 & 0.0470712 & 0.8282948 & & \\
\hline \multicolumn{5}{|c|}{ Granger Causality Test: $X=f(Y)$} & & \\
\hline Model & Res.DF & $\begin{array}{l}\text { Diff. } \\
\text { DF }\end{array}$ & $\mathrm{F}$ & p-value & Occurrence & $\begin{array}{l}\text { Accept/ } \\
\text { Reject }\end{array}$ \\
\hline $\begin{array}{l}\text { Complete } \\
\text { model }\end{array}$ & 812 & & & & 0.375317635 & Reject \\
\hline $\begin{array}{l}\text { Reduced } \\
\text { model }\end{array}$ & 813 & -1 & 0.23952391 & 0.62468237 & & \\
\hline
\end{tabular}

Nifty 50 Shariah is a function of NIFTY 500 Sharia

\section{Discussion}

Table 7 - Results of research

\begin{tabular}{lll}
\hline & $\mathrm{Y}=\mathrm{f}(\mathrm{X})$ & $\mathrm{X}=\mathrm{f}(\mathrm{Y})$ \\
\hline S\&P BSE 500 Shariah $(\mathrm{X})$ - NIFTY Shariah 25(Y) & Reject & Reject \\
S\&P BSE 500 Shariah $(X)$ - NIFTY 50 Shariah(Y) & Reject & Accept \\
S\&P BSE 500 Shariah $(X)$ - NIFTY 500 Shariah(Y) & Reject & Accept \\
Nifty Shariah 25(X)- NIFTY 50 Shariah(Y) & Reject & Accept \\
Nifty Shariah 25(X)- NIFTY 500 Shariah(Y) & Reject & Accept \\
Nifty 50 Shariah $(X)$ - NIFTY 500 Shariah(Y) & Reject & Reject \\
\hline
\end{tabular}

In S\&P BSE 500 Shariah(X) - NIFTY Shariah 25(Y) and Nifty 50 Shariah $(X)$ - NIFTY 500 Shariah(Y), there is no relation in both stock market indices. Therefore, Granger Causality does not clearly indicate which stock market index is the function. In other words, it is difficult to understand who the driver is and who is getting driven. Whereas, in other stock market indices, it can be seen that $\mathrm{X}=\mathrm{f}(\mathrm{Y})$ is being accepted. This implies:

S\&P BSE 500 Shariah $=\mathrm{f}($ NIFTY 50 Shariah)

Here S\&P BSE 500 Shariah is the function of NIFTY 50 Shariah. This means NIFTY 50 Shariah is the driver and S\&P BSE 500 Shariah is being driven. On studying NIFTY 50 Shariah, the performance of S\&P BSE 500 Shariah can be understood. 
S\&P BSE 500 Shariah $=\mathrm{f}($ NIFTY 500 Shariah $)$

Here S\&P BSE 500 Shariah is the function of NIFTY 500 Shariah. This means NIFTY 500 Shariah is the driver and S\&P BSE 500 Shariah is being driven. On studying NIFTY 500 Shariah, the performance of S\&P BSE 500 Shariah can be found.

Nifty Shariah 25= f (NIFTY 50 Shariah)

Here Nifty Shariah 25 is the function of NIFTY 50 Shariah. This means NIFTY 50 Shariah is the driver and Nifty Shariah 25 is being driven. On studying NIFTY 50 Shariah, the performance of Nifty Shariah 25 can be found.

Nifty Shariah 25 = f (NIFTY 500 Shariah)

Here Nifty Shariah 25 is the function of NIFTY 500 Shariah. This means that NIFTY 500 Shariah is the driver and Nifty Shariah 25 is being driven. On studying NIFTY 500 Shariah, the performance of Nifty Shariah 25 can be found.

\section{Conclusion}

The paper concludes that if the investor follows the NIFTY 50 Shariah, the investor can easily predict the future performance of the S\&P BSE 500 Shariah and Nifty Shariah 25. In this, S\&P BSE 500 Shariah and Nifty Shariah 25 are been driven by NIFTY 50 Shariah who is the driver in this case. If the investor follows the NIFTY 500 Shariah, the investor can predict the future performance of the S\&P BSE 500 Shariah and Nifty Shariah 25. In this case, again the S\&P BSE 500 Shariah and Nifty Shariah 25 are been driven by the NIFTY 500 Shariah which is the driver. In other words, the investor needs to follow any one of the stocks from NIFTY 50 Shariah or NIFTY 500 Shariah to know the performance of the driven stocks. Therefore, it is understood that if the investor is following NIFTY Shariah 25, he/she cannot make future decisions for S\&P BSE 500 Shariah as it is not being driven by the NIFTY Shariah 25 . The same reason applies to the investor following NIFTY 500 Shariah and deciding for Nifty 50 Shariah. Further, if the investor wishes to know about the stock, he can do the Granger Causality in between the two stocks to enable him to have clarity before investing. 


\section{References}

Dharani, M., \& Natarajan, P. (2011, May). Equanimity od Risk and Return Relationship between Shariah Index and General Index in India. Journal of Economics and Behavioral Studies, 2(5), 213-222.

Dharani, M., Vijayakumar, N., \& Natarajan, P. (2015). An Empirical Study on Volatility Pattern of the Shariah Compliant Stocks in Indian Capital Market. Journal of Economic Policy and Research, 10(2), 150-165.

Ghosh, B., \& Srinivasan, P. (2013, December). Shariah Investment In India -An Unexplored Opportunity. International Journal of Innovative Research and Development, 2(12), 33-37.

Ghosh, B., \& Srinivasan, P. (2015). Rationale of investing to re-script the India story- A case on CNX Shariah. Re Scripting India's Growth Story CMS B School Jain University Bangalore.

Irfan, M., \& Tanwar, S. (2017, July). Are Shariah and Non-Shariah indices related? Some empirical evidence from India. ISOR Journal of Business and Management (ISOR-JBM), 19(7), 01-09.

Karim, B. A., Linn, J. F., \& Karim, Z. A. (2017, August). Determinants of the Islamic stock markets integration. Accounting and Finance Research, 6(3), 147-152.

Khatakhatay, M. H., \& Nisar, S. (2007, July). Shariah compliant equity investments: an assessment of current screening norms. Islamic Economic Studies, 15(1), 47-76.

Mansoori, M. T. (2011). Is "Islamic Banking" Islamic? analysis of current debate on shariah legitimacy of islamic banking and finance. Islamic Studies, 50(3/4), 383-411.

Mohammad, I. (2016, July). A study of Islamic stock indices and macroeconomics variables. International Journal of Social, Behaviour, Economic, Business and Industrial Engineering, 10(7), 2557-2565.

Natarajan, P., \& Dharani, M. (2012, January). Shariah compliant stock in india - a viable and ethical investment vehicle. Arabian Journal of Business and Management Review (OMAN Chapter), 1(6), 50-62.

Nisar, S. (2002). The state of Islamic finance in India: strengths and weaknesses. Review of Islamic Economics, 12, 87-99.

Nisar, S. (2008, July). Islamic investments opportunities in India. Retrieved from www.shraiqnisar.com, 1-12.

Sharia. (July, 2019). Retrieved from https://en.wikipedia.org/wiki/Sharia

Singh, A., \& Sheng, A. (2013, January). Islamic stock markets in global context. Munich Personal RePEc Archive, 27.

Tyagi, A. K., \& Rizwan, M. (2012, December). A study of the movement of BSE-TASIS Shariah 50 index in accordance with Sensex. International Journal of Emerging Research in Management E Technology, 5-13. 